\title{
СТРУКТУРУВАННЯ ПРОЦЕСУ АВТОМАТИЗАЦІї САДІННЯ ЖИВЦІВ ЕНЕРГЕТИЧНОЇ ВЕРБИ
}

\author{
Єрмаков Сергій Володимирович \\ завідувач навчально-наукової лабораторії «DAK GPS» \\ Подільський державний аграрно-технічний університет, м. Кам'янець-Подільський, Хмельницька область, Україна \\ ORCID: 0000-0002-6840-5309 \\ dakgps@pdatu.edu.ua
}

Гуцол Тарас Дмитрович

доктор технічних наук, доцент

Поліський національний університет, м. Кам'янець-Подільський, Хмельницька область, Україна

ORCID: 0000-0002-9086-3672

pro-gp@pdatu.edu.ua

Потапський Павло Васильович

кандидат технічних наук, доцент

Подільський державний аграрно-технічний університет, м. Кам'янець-Подільський, Хмельницька область, Україна

ORCID: 0000-0003-4792-8992

p.v.potap@meta.ua

Гарасимчук Ігор Дмитрович

Подільський державний аграрно-технічний університет

ORCID: 0000-0002-4304-4447

igorgarasymchuk@gmail.com

Енергія біомаси є однією із найперспективніших галузей відновлювальної енергетики передусім через можливість швидкого нарощування обсягів виробництва сировини. Створення нових насаджень енергетичних культур потребує відповідних технічних засобів. А для енергетичної верби чи тополі слід також ураховувати особливості садивного матеріалу, яким є здерев'янілі живці довжиною 20-25 см і діаметром 6-16 мм. Відомі машини для садіння живців енергетичних культур характеризуються малою продуктивністю внаслідок обмеження швидкості ручного закладання живців у садильний апарат. Тому створення механізмів для автоматизованого закладання живців у садильні апарати є актуальним науковим і виробничим завданням.

Дослідження грунтується на аналізі відомих конструкцій автоматів садіння, що використовуються під час садіння розсади і саджаниів для лісу. Під час роботи використовувалися методи структурно-фракторного аналізу щодо будови механізмів; виділялись особливості робочих процесів, які відбуваються на кожному з етапів загального технологічного процесу переміщення живців від технологічної ємкості до місия садіння.

Проаналізувавши відомі технічні рішення про садіння лісу, розсади, горшкових матеріалів і живців енергетичних культур, відмічено, що найбільш проблемною є позиція, що відповідає за подачу живців від ємкостей із розсадою до місця садіння. У сучасних машинах для садіння енергетичної верби цей процес виконується винятково вручну. Інформаційно-логічні пошуки призвели до синтезування структурно-логічної схеми технологічного процесу автоматизованого садіння. Зәідно із цією схемою, основними операціями, які необхідно реалізувати в автоматі садіння, є звуження потоку живців, поштучний відбір, орієнтування і транспортування садивного матеріалу до місия садіння. Виокремлено перспективні способи автоматизації садіння живців енергетичних культур і можливі проблеми на шляху до їх реалізації.

Ключові слова: автомат садіння, саджалка, механізм подачі, касетний механізм, садильний апарат, енергетична верба.

DOI https://doi.org/10.32845/msnau.2021.3.2

Вступ. Поширення енергетичних стратегій щодо збільшення частки відновлювальної енергії у загальній структурі енергоспоживання країн змушує звертати увагу на такі види поновлювальних джерел, як енергія біомаси. Важливим напрямком розвитку цього є виробництво палива та енергії із швидкорослих енергетичних рослин, що, у свою чергу, зумовлює необхідність створення високопродуктивних машин для закладання насаджень енергетичних культур, що потребує перегляду технічних засобів для виконання технологічних процесів вирощування біомаси і пошуку шляхів покращення їхньої продуктивності.
Однією із пріоритетних енергетичних культур для освоєння є верба, здатна за короткий час продукувати значну кількість біомаси, невибаглива до рельєфу і структури грунтів, добре пристосована для кліматичних умов України, досить технологічна щодо зручності вирощування і збирання врожаю. Специфікою цієї культури є те, що у промислових цілях вона розмножується вегетативним способом. Оптимальним садивним матеріалом для створення енергетичних плантацій верб є однорічні здерев'янілі живці завдовжки 20-30 см і завтовшки 5-15 мм (Frączek et al., 2005), які можна розглядати як стрижне- 
подібні об'єкти, проте під час роботи з ними слід ураховувати можливі нерівності, конусність, наявність вічок на бічній поверхні (рис. 1). Такий садивний матеріал заготовляють із однорічних пагонів верби. Для садіння одного гектара потрібно 15-20 тис. живців, а під час закладання маточних насаджень - до 30 тис. (Roik et al., 2015).

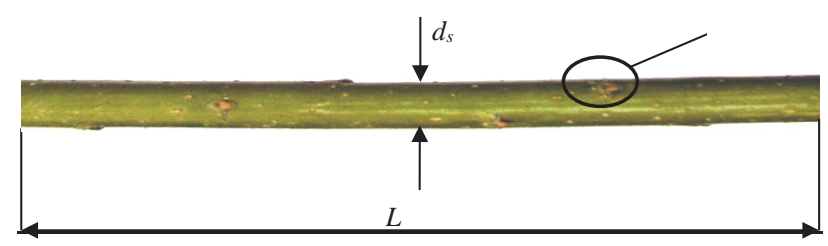

Рис. 1. Живець енергетичної верби: $d_{s}$ - діаметр живця, виміряний на половині довжини, $L$ - довжина живця, 1 - вічка на бічній поверхні розсади

Для швидкого закладання «плантації» енергетичної верби потрібна машина для садіння, яка б могла працювати із таким матеріалом. Машини для садіння енергетичної верби, наявні нині, можна поділити на дві групи: із використанням живців відповідного розміру та із закладанням довгих прутів верби (2,5...6 м) із розрізанням їх самою машиною саме перед садінням у борозну (Wrobel et al., 2018; Sinchenko et al., 2015). Проте в усіх відомих машинах для садіння верби для закладки садивного матеріалу використовується праця садівника. Розроблення автомату садіння суттєво розширило би можливості збільшення продуктивності агрегата, усуваючи людський фактор під час його виконання.
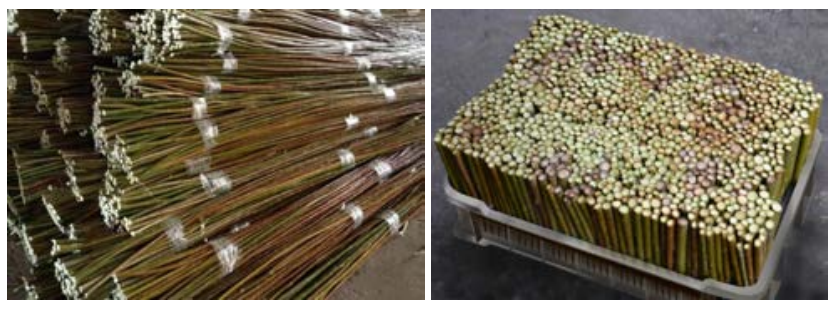

Рис. 2. Садивний матеріал енергетичної верби:

а) у разі садіння прутами $(/=2,5-6,0 \mathrm{M})$, б) у разі садіння завчасно підготовленими живцями (I = 20-25 см)
Рішення цього питання можна знайти у галузях, де використовується такий садивний матеріал, зокрема у лісівництві та садінні розсади.

Стосовно проблеми вдосконалення складного і трудомісткого процесу садіння розсади і деревних культур уже понад століття робота триває за кількома напрямками, починаючи від поліпшення окремих робочих органів саджалок і до спроб автоматизувати процес, що дозволить звільнитися від ручної праці та негативних чинників, які випливають унаслідок її використання (поріг продуктивності подачі садивного матеріалу, залежність якості від фізіологічного стану оператора тощо). Водночас над удосконаленням роботи саджалок працюють як цілі наукові інститути країн, так і окремі науковці та дослідники, які пропонували власні конструкції саджалок із автоматизованим виконанням процесу. Щоправда, перші спроби автоматизувати процес садіння зводилися переважно до використання різних транспортерів подачі. Водночас розсада заздалегідь закладалась у спеціальні стрічки із гніздами, пружними тримачами чи іншими утримуючими пристосуваннями. Стрічка згортається у рулон (касету), під час розгортання рулону стрічка переміщається на крок, кратний кроку садіння; розсада почергово вихоплюється зі стрічки захватами садильного апарату і спрямовується до місця садіння. Таким чином, послідовність, ритмічність і крок подачі садивного матеріалу формується і забезпечується параметрами стрічки, переміщення якої змінює як загальне положення, так і орієнтування його у просторі. Основним недоліком таких автоматів $€$ велика трудомісткість «заряджання» рослин у стрічки касет, через що цю операцію перенесено з основного процесу; її виконують заздалегідь перед садінням. Окрім цього, наявність касетного механізму підвищує складність конструкції саджалок та їхню громіздкість, а також знижує надійність виконання процесу через такі недоліки касетних механізмів, як сходження зі стрічок опорних направляючих роликів і працездатність елементів кріплення рослин у стрічці.

Такий спосіб автоматизації процесу і нині $є$ актуальним, зокрема відомі такі касетні автомати, як ПЛА-1 (рис.3а), АПА-1, які успішно використовуються під час садіння саджанців лісових культур.

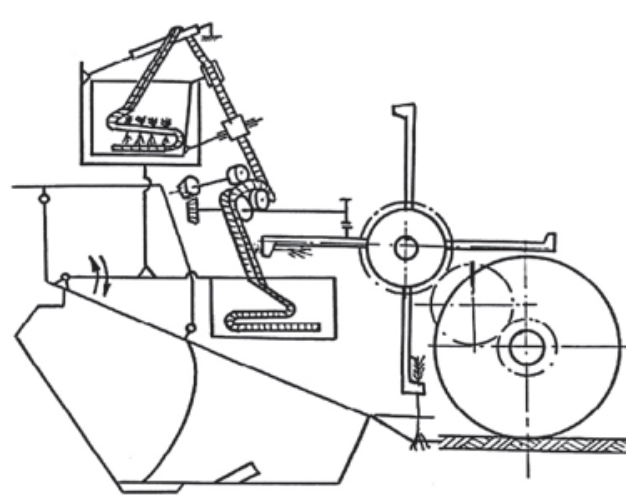

a

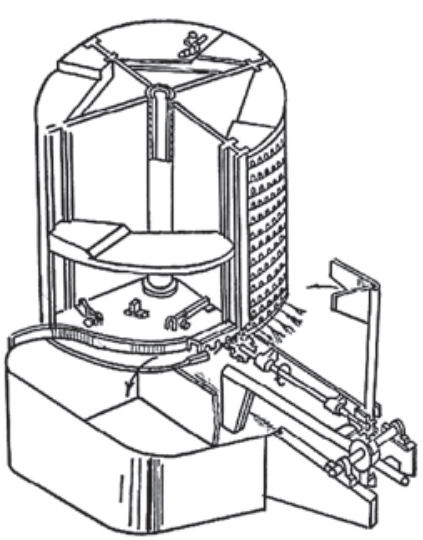

6

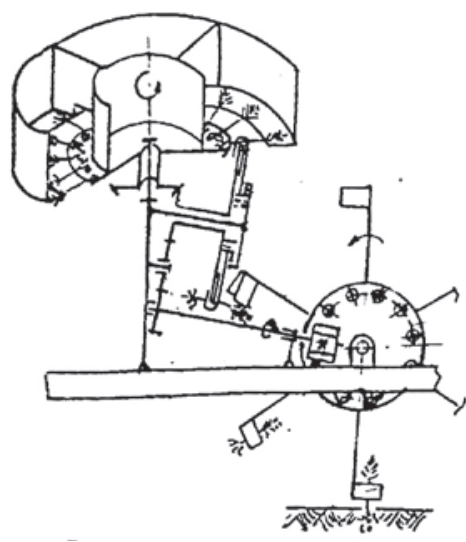

B

Рис. 3. Автомати садіння: а) із гнучкою касетою (ПЛА-1); б) із жорсткою касетою (АЛП-1); в) автомат АБС-6 без касети для сіянців 
Подібний принцип роботи мають автомати із жорсткими касетами, які виконуються у вигляді плоских елементів (автомат ЛДМ-21) або барабанів (автомат АЛП-1, зображений на рис.3б). Головною їх відмінністю $€$ дугове переміщення касет на крок подачі до місця відбору садивного матеріалу захватами садильного апарату (Bartenev, 2012). Тут формування маси садивного матеріалу визначається параметрами жорстких касет, а переміщення - режимами їх обертання.

Садильні автомати із жорсткими касетами порівняно з автоматами із гнучкими касетами є компактнішими і не вимагають додаткового переміщення під час зарядки сіянцями. Водночас операції подання касет із бункера до захватів садильного апарату саджалки і звільнення касети від сіянців потребують додаткового вивчення для кожного садивного матеріалу.

Як і у випадку із гнучкими касетами, вагомим недоліком такого способу $є$ необхідність попереднього «заряджання» касет. Це вимагає розроблення додаткових механізмів, адже ручна зарядка стрічки потребує багато часу, наприклад, заряджання стрічки із гніздами на 2000 рослин німецької машини «Шонхер» тривало 3,5 години (Evseev, 1977). Отже, загальні витрати часу на виконання процесу садіння рослин мало змінюються, тому говорити про ефективність касетних механізмів подачі рослин можна лише у контексті роботи тільки садильного агрегату.

До загальних недоліків касетних автоматів подачі відносять також тривалий час перебування рослин на повітрі, що важливо для деяких видів садивного матеріалу, зокрема із відкритою кореневою системою. Цей час не повинен перевищувати п'яти хвилин, інакше різко знижується приживаність рослин і сповільнюється їхній ріст (Bartieniev, 2012; Yermakov, Borys, 2016; Yermakov, 2018). Фактично рослину перед садінням витримують не лише протягом технологічного часу, коли ії переміщують із бункера на місце садіння, але і часу, пов'язаного із технічними зупинками внаслідок усунення несправностей, що виникають.

Суттєвим недоліком касетних автоматів є також те, що для забезпечення їх роботи потрібен ретельний відбір сіянців із загальної маси за розмірами, будовою кореневої системи і крони тощо. Інші сіянці вибраковуються і їхнє висаджування потрібно виконувати ручними способами. Зазвичай частка такого матеріалу становить до 50\% (Bartenev, 2012, Yermakov et al., 2018).

Технічні рішення 3 автоматизації процесу садіння відомі у разі садіння розсади у горщики. За такої умови розсаду заздалегідь вирощують у спеціальних касетах із комірками, звідти розсаду подають до підготовленого місця садіння. Однакова фрорма горщиків, яка чітко орієнтує розсаду у вертикальній площині, дозволяє краще використовувати цю властивість під час завантаження. Зокрема, задля усунення залежності якості виконання процесу від можливостей людини у поштучному відборі предметів (як зазначалося, людина може відібрати 40-60 шт. за хвилину без належної однорідності відбору і швидко втомитися через монотонність роботи), створюються умови для більш зручного встановлення розсади. Для цього перед садильним апаратом створюється деякий запас садивного матеріалу, який накопичується у спеціальних розподільниках (карусельного (рис. 4б) або револьверного (рис.4а) типу), або на скатних дошках (рис.4в). Цей запас створюється людиною, але без жорстких умов за ритмічністю (однаковий час між сіянцями) і з можливістю відбору не поштучно, а блоками. Звідти розсада автоматично із заданими параметрами видається у садильний апарат. Такі машини у садінні розсади називаються semi-automat. Отже, такі пристосування можуть суттєво збільшити продуктивність садіння, підвищити якість надходження садивного матеріалу до місця садіння (точну орієнтацію і координати), а також дозволяють установити механізм контролю за неповноцінною розсадою або її відсутністю. Недоліком можна назвати ускладнення конструкції і збільшення вартості машини. У випадку зі скатними дошками важливою $є$ також можливість транспортування рослин на її поверхні.

Револьверні розподільники помічені і в окремих машинах для садіння енергетичної верби довгими прутами. Для садіння горщикової розсади у касетах уже існують закордонні машини, в яких людина лише слідкує за своєчасним поповненням касет, а все інше відбувається автоматично. У них розсада виштовхується із касет спеціальними штовхачами, які наперед програ-

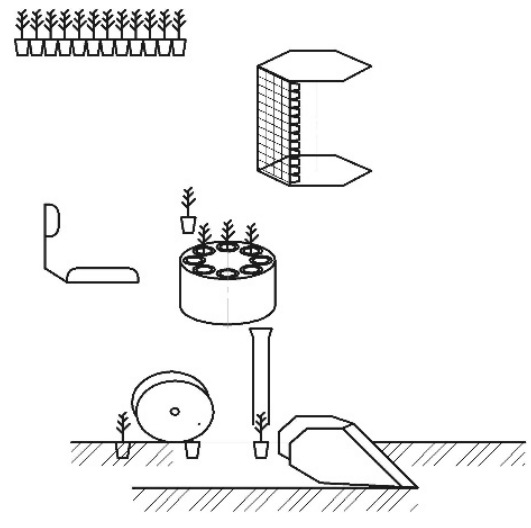

a

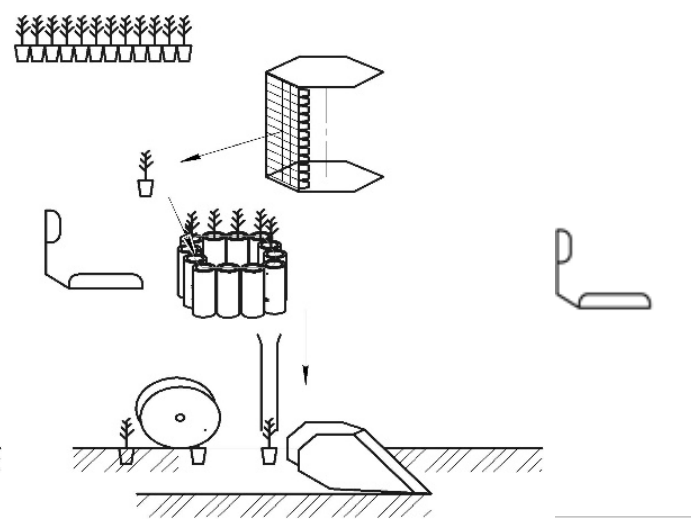

6

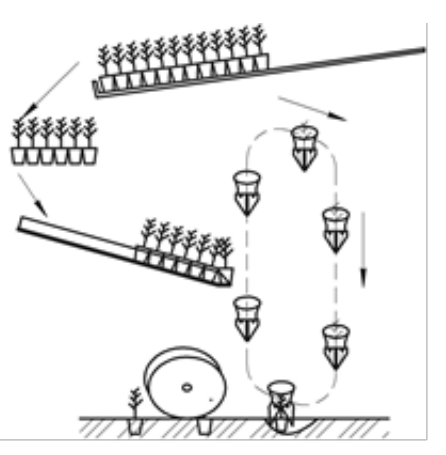

B

Рис. 4. Саджалки із розподільниками револьверного (а) і карусельного (б) типу та 3 автоматизованою подачею розсади скатними дошками (в) 
муються на координатну сітку касет. Після звільнення із касет горщикова розсада спеціальними важільними пристроями змінює орієнтування на вертикальне, водночас опускається у розподільник накопичувач, який у такому положенні спрямовує розсаду до місця садіння.

Затрати праці на заряджання стрічок касетних автоматів, несумісність механізмів автоматизації для горщикової розсади із вимогами до садіння саджанців і живців вимагали пошуку конструкцій механізмів без касет. Головною проблемою в них став захват рослин із бункера. Існує багато ідей на рівні патентів, які по-різному вирішували це завдання, але реальна конструкція зустрічається у вигляді автомата без касети АБС-6 для саджанців (рис. Зв). Основними вузлами автомата є бункер для сіянців у вигляді циліндра обертання з округлим прорізом у днищі для проходження робочих елементів і механізм вибирання сіянців (Zyma, 2006). Для роботи такого автомата садіння потрібно, щоб у бункері перед роботою було сформовано відносно упорядкований масив садивного матеріалу, тобто первісне формування поодинокого руху саджанців має здійснюватися вручну. Захвати, зберігаючи орієнтування, переносять їх у зону дії захватів садильного апарату.

Нині триває робота над удосконаленням процесу садіння рослин. Багато праць аналізують як теоретичні аспекти автоматизації (Bartenev, 2012; Miwa et al., 1991; Kasimov et al., 2015 та інші), так і автоматизацію конкретного виду рослин (Usenko, 2010; Asmolovskyi et al., 2004 та інші), навіть до впровадження робототехніки у процес садіння (Kutz et al., 1994; Mao et al., 2014 та інші). Проте кожен конкретний вид рослин потребує конкретного підходу. Зокрема, енергетична верба потребує врахування виду садивного матеріалу (живці довжиною 20-25 см).

Матеріали і методи досліджень. Через недостатній розвиток автоматизації садіння енергетичних деревних культур метою роботи $є$ пошук перспективних шляхів і дієвих принципів забезпечення автоматизації процесів під час роботи саджалок.

Дослідження здійснювалося на основі структурно-фракторного аналізу технічних рішень наявних автоматів садіння. Для виділення характерних ознак конкретних машин застосовувалися методи структуризації об'єкту та абстрагування від ознак, які не впливають на досліджуваний процес.

Результати. Нині науковці працюють над вирішенням проблеми садіння розсади, лісу, садів і виноградників у таких напрямках:

- забезпечення роботи саджалок на підвищених швидкостях;

- зниження затрат ручної праці для обслуговування садильних машин;

- покращення умов праці.

Вирішити ці завдання можна шляхом передачі функцій саджальників автоматичним системам виконання і регулювання технологічного процесу садіння. Донині накопичено певний досвід у розробленні та застосуванні автоматів подачі рослин у захвати садильного апарата. Засоби автоматизації умовно можна поділити на такі види:
- накопичувачі зі скатними дошками або розподільниками;

- автомати із гнучкими або жорсткими касетами;

- автомати без касет.

У всіх них є переваги і недоліки, але ці конструкції неможливо використати для садіння енергетичних деревних культур. Головним відмінним фактором $€$ тип садивного матеріалу - енергетичні культури садять живцями довжиною 20-25 см і діаметром 8-20 мм, що суттєво відрізняється за своїми характеристиками від рослин із відкритою кореневою системою або від розсади у горщиках.

Основною перешкодою подальшого підвищення продуктивності саджалок $є$ обмеженість можливостей людини у подачі живців - 40-60 шт./хв. (Bartenev, 2012), що відповідає швидкості поступального руху машини 0,8...2,1 км/год. У цих умовах важливо замінити працю оператора засобами автоматизації. Тому актуальним $€$ пошук перспективних технологічних процесів і конструкцій робочих органів для автоматизованої подачі живців у машинах для садіння енергетичних деревних культур, що структурно можна відобразити схемою (рис. 5).

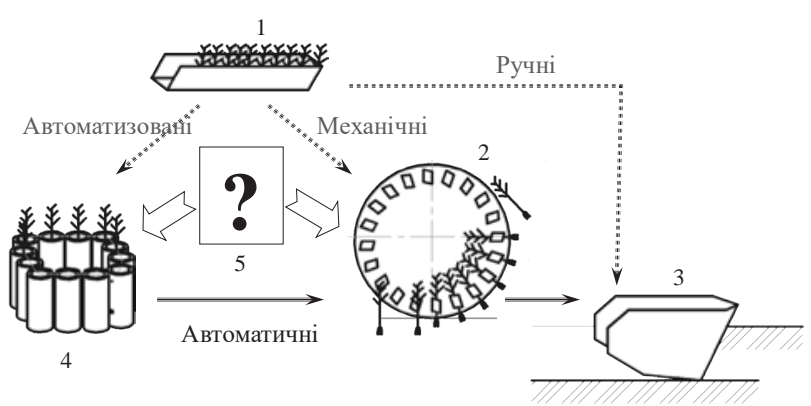

Рис. 5. Структурно-логічна схема виконання операцій процесу садіння живців енергетичної верби: 1 - місткість із розсадою; 2 - садильні апарати; 3 - сошники чи обладнання, що утворює борозни; 4 - накопичувачі садивного матеріалу; 5 - механізм подачі живців

У сучасних машинах для садіння енергетичної верби цей процес виконується винятково вручну (Yermakov, 2017, Hutsol, 2018).

Проаналізувавши різноманітні конструкції, ми дійшли висновку, що для підвищення продуктивності садильних машин слід удосконалити процес подачі живців від ємкостей до садильного апарату. Окрім того, потрібно використовувати проміжні накопичувачі живців, що дозволяють створити буфер, який компенсує невідповідність продуктивності садильного апарату і можливостей людини. Але це лише частково вирішує питання про підвищення продуктивності та зменшення частки ручної праці.

Створення механізмів для автоматизованої подачі живців до садильного апарату чи прямо до місця посадки $€$ важливим науковим завданням на шляху збільшення продуктивності садильних машин.

Унаслідок аналізу літературних джерел та електронних ресурсів, досвіду окремих виробників садильної техніки нами синтезовано загальну структурно-логічну схему можливих варіантів виконання технологічного процесу подачі живців (рис. 6). 


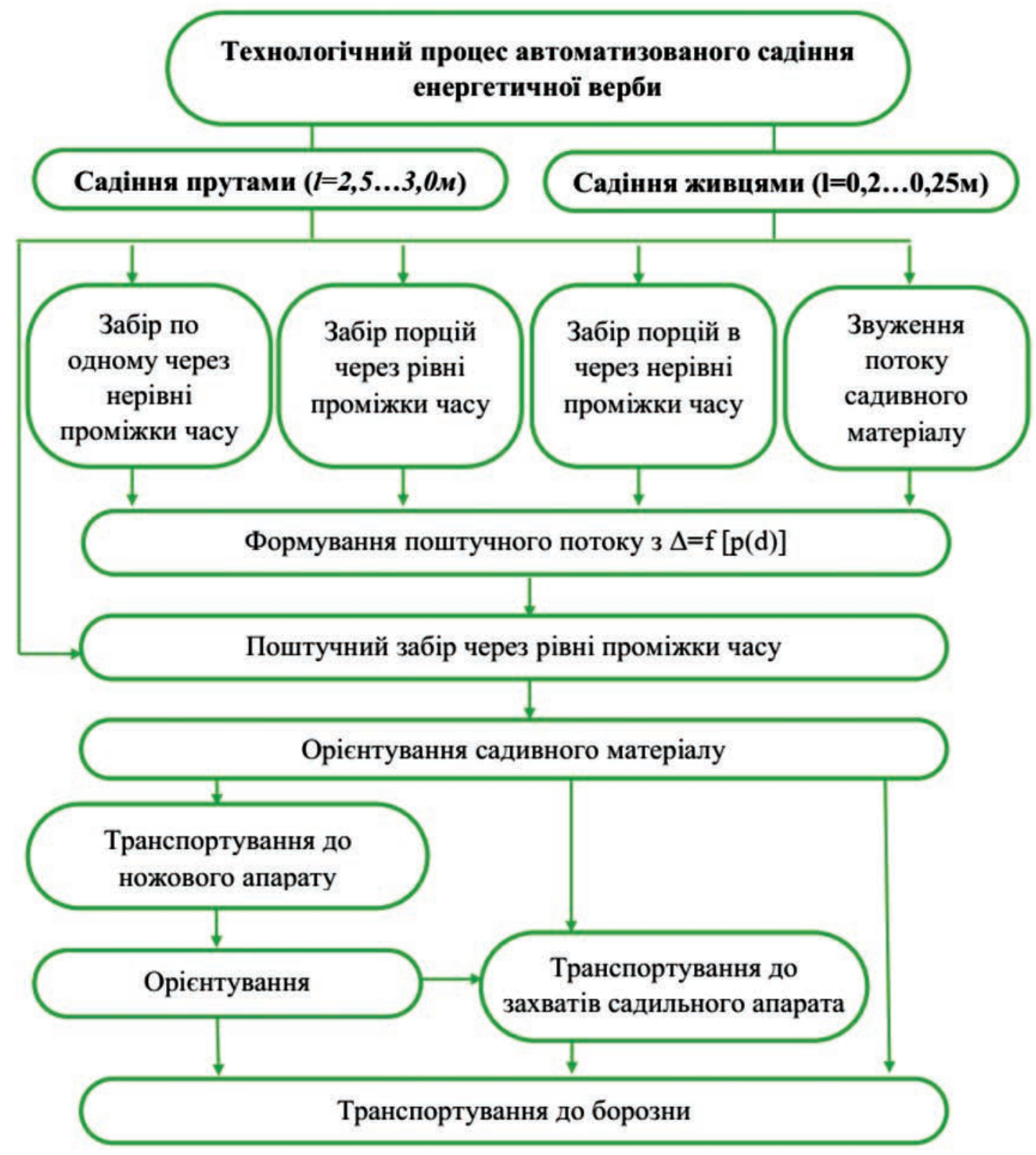

Рис. 6. Структурно-логічна схема можливих варіантів виконання технологічного процесу подачі живців

Обговорення. Корінним вирішенням проблеми садіння енергетичної верби на підвищених швидкостях і зниження затрат людської праці $€$ передача фрункцій саджальників автоматичним системам виконання і регулювання технологічного процесу садіння (Asmolovskyi et al., 2004; Yermakov, 2017). Удосконалення конструкції окремих елементів машин і зміни у засобах, що утворюють борозни (наприклад введення у конструкцію сошника додаткових органів заорювання) і засобів, що заорюють ґрунт (використання пневматичних шин), дозволяють збільшити швидкість поступального руху до 6,5 км/год. Однак повністю реалізувати можливості процесу садіння можна лише за умови автоматизації подачі садивного матеріалу у захвати садильного апарату чи прямо у борозну. Для цього саджалки деревних енергетичних культур мають бути оснащені механізмами автоматизованого відбору, орієнтування і транспортування живців до місця садіння. На нашу думку, найпростішим варіантом вирішення цієї проблеми $є$ застосування завантажувального пристрою бункерно-магазинного типу із вільним висипанням завчасно орієнтованих живців із подальшим їх розділенням на порції. Унаслідок попередніх досліджень нами встановлено, що під час руху тіл у цьому бункері неодмінно виникають такі явища, як утворення склепів, перекоси у горизонтальній і вертикальній площинах, заклинювання тощо (Yermakov, Hutsol, 2018; Yermakov et al., 2019; Yermakov et al., 2019; Yermakov, 2019; Ivanyshyn et al., 2020; Yermakov, Hutsol, 2021). Ми пропонуємо для здійснення технологічного процесу виконати такі операції: 
- забезпечити вільне висипання живців із бункера;

- забезпечити звуження потоку живців;

- створити поштучний потік;

- забезпечити забір живців із поодинокого потоку;

- забезпечити правильне орієнтування живців під час руху.

Висновки. Унаслідок аналізу конструкцій наявних засобів автоматизації садіння і способів здійснення процесу автоматизованої подачі садивного матеріалу виділено можливі шляхи організації різних способів у технологічний процес, що відображено у структурно-логічній схемі процесу. Виокремлено перспективні шляхи автоматизації садіння живців енергетичних культур, для забезпечення яких потрібно враховувати, що:

- найбільшою проблемою під час створення автоматів садіння $€$ автоматизація процесу подачі садивного матеріалу від накопичувальної ємкості до місця садіння;

- для живців енергетичних культур найдоцільніше шукати рішення в автоматах без касет;

- під час вирішення питань ми стикаємось із такими проблемами, як склепоутворення, перекоси тощо;

- виокремлення структури процесу дозволить системно підійти до пошуку рішення.

\section{Бібліографічні посилання:}

1. Aijun, G., Xiaoyu, L., Jialin, H., Zhilong, Z., Ji, Z., Jun, C. (2018). Design and experiment of automatic directing garlic planter [J]. Transactions of the Chinese Society of Agricultural Engineering (Transactions of the CSAE), 2018, 34(11):17-25. https://doi.org/10.11975/j. issn.1002-6819.2018.11.003

2. Asmolovskyi, M.K., Loi, V.N., Zhukov, A.V. (2004). Mekhanizaciya liesnogo i parkovogo hoziaystva (Mechanization of the forest, park and garden management). BSTU, Minsk. 450 p. (in Russian).

3. Baran, D., Kwaśniewski, D., Mudryk K. (2007). Wybrane właściwości fizyczne trzyletniej wierzby energetycznej. Inżynieria Rolnicza. V. 11. pp. 7-12.

4. Bartenev, I.M. (2012). Automatizaciya processa posadki rasteniy (Automation of the planting process). Scientific journal of the KubSAU 75(01), pp. 384-396 (in Russian).

5. Bartenev, I.M. (2017). Innovacionnye napravleniya tekhnicheskogo razvitiya lesnogo hozyajstva i zashchitnogo lesorazvedeniya (Innovative directions of technical development of forest management and protective forcession). Aktual'nye napravleniya nauchnyh issledovanij XXI veka: teoriya i praktika. T.5. pp. 307-309 (in Russian).

6. Borys, M.M., Yermakov, S.V. (2017). Perspektyvy avtomatyzatsii sadinnia zhyvtsiv enerhetychnykh kultur (Prospects for automation of planting cuttings of energy crops). Zbirnyk naukovykh prats Mizhnarodnoi naukovoi konferentsii. KamianetsPodilskyi, 2017. pp. 23-26 (in Ukrainian).

7. Bush, C., Volk, T.A., Eisenbies H. (2015). Planting rates and delays during the establishment of willow biomass crops. Biomass and Bioenergy. V.83, 290-296 https://doi.org/10.1016/j.biombioe.2015.10.008

8. Dziedzic, K., Łapczyńska-Kordon, B., Mudryk, K. (2017). Decision support systems to establish plantations of energy crops on the example of willow (Salix Viminalis L.). Scientific achievements in agricultural engineering, agronomy and veterinary medicine polish ukrainian cooperation. Vol. 1, No. 1, pp. 150-160.

9. Evseev, L. (1977) Rassadoposadochnaya mashina. Tekhnika molodezhi, 09

10. Frączek, J., Mudryk, K. (2005). Jakości sadzonek wierzby energetycznej w aspekcie sadzenia mechanicznego. Inżynieria Rolnicza, 6 (66),159-167.

11. Galle, D.T. (2012). Development of an automated precision planter for establishment of Miscanthus giganteus. Purdue University. ProQuest Dissertations Publishing, 2012. 10156261.

12. Hutsol T., Glowacki S., Mudryk K. Agrobiomass of Ukraine - Energy Potential of Central and Eastern Europe (Engineering, Technology, Innovation, Economics). Monograph. Warsaw: 2021. 136 p.

13. Hutsol, T., Yermakov, S., Firman, Ju, Duganets, V., Bodnar, A. (2018). Analysis of technical solutions of planting machines, which can be used in planting energy willow Renewable Energy Sources: Engineering, Technology, Innovation. pp. 99-111. https://doi.org/10.1007/978-3-030-13888-2_10.

14. Ivanyshyn, V., Yermakov, S., Ishchenko, T., Mudryk, K., Hutsol, T. (2020). Calculation algorithm for the dynamic coefficient of vibroviscosity and other properties of energy willow cuttings movement in terms of their unloading from the tanker. E3S Web of Conferences, 154, 04005. https://doi.org/10.1051/e3sconf/202015404005.

15. Kasimov, N.G., Konstantinov, V.I., Kutiavin, A.S. (2015). Klassifikaciya rassadoposadochnyx mashy`n po osnovnym pry`znakam funkcy ony rovany ya. [Classification of seedlings planters according to the main operating principles]. Vestnik of the Izhevsk State Agricultural Academy, 3 (44), pp. 20-25. (in Russian)

16. Kravchuk, V., Novokhatskyi, M., Kozhushko, M., Dumych, V., Zhurba, H. (2013). Na shliakhu do stvorennia plantatsii enerhetychnykh kultur (On the way to creating energy plantations). Tekhnika i tekhnolohii APK, № 2 (41) (in Ukrainian).

17. Kucher, O., Prokopchuk, L. (2019). Economic aspects of biomass market development in Ukraine. Renewable Energy Sources engineering, technology, innovation. Krynica. pp. 12-14. https://doi.org/10.1051/e3sconf/202015401007.

18. Kucher, O., Prokopchuk, L. (2017). The development of the market of the renewable energy in Ukraine. Renewable Energy Sources: Engineering, Technology, Innovation. Springer International Publishing AG. pp. 71-81. https://doi. org/10.1007/978-3-319-72371-6_8.

19. Kutz, L.J., Craven, J.B. (1994). Evaluation of photoelectric sensors for robotic transplantation. Applied Engineering in Agriculture, 10 (1), pp.115-121.

20. Liu, K., Cheng G. and Kong, Z. (2019). Beidou agricultural machinery automatic driving software design, 2019 IEEE 4th Advanced Information Technology, Electronic and Automation Control Conference (IAEAC), pp. 1770-1775, https://doi. org/10.1109/IAEAC47372.2019.8997712

21. Lys, S.S. (2009). Ohliad tekhnolohii hazyfikatsii derevyny (Review of wood gasification technology). Naukovyi visnyk NLTU Ukrainy: zb. nauk.-tekhn. prats. Lviv (in Ukrainian) 
22. Manual seedling planter PPM-1. Technical details and operations manual Retrieved: http://www.rosta.ua/pics/ passport/rrm1.rar, Access: 20.10.2021.

23. Mao, H., Han, L., Hu, J., Kumi, F. (2014). Development of a pincette-type pick-up device for automatic transplanting of greenhouse seedlings. Applied engineering in agriculture, 30(4), pp. 547-556.

24. Mitkov, V., Kiurchev, S., Nurek, T., Chorna, T., Innatiev, Ye. (2021). Scientific bases of aggregation of combined units on the basis of an integrated tractor. Monograph. Warsaw.

25. Miwa, Y. (1991). Automation of plant tissue culture process. In Automation in biotechnology: a collection of contributions presented at the Fourth Toyota Conference, Aichi, Japan, Amsterdam: Elsevier.

26. Mudryk K, Hutsol T., Ovcharuk O. (2021). Określenie rozłożenia pędów wierzby energetycznej. Trends and challenges of modern agricultural science: theory and practice, Kyiv, pp. 20-22.

27. Roik, M.V., Sinchenko, V.M., Fuchylo, Y.D. (2015). Energety`chna verba: texnologiya vy'roshhuvannya ta vy`kory`stannya (Energy willow: cultivation technology and usage). LLC “Nilan-LTD”, Vinnitsa, p.340 (in Ukrainian).

28. SALIX energy. Retrieved: https://www.salix-energy.com. Access: 20.10.2021.

29. Seedling planters. Retrieved: http://www.agro-sistema.ru/index.php? option=com_content\&view=article\&id=89\&lte mid=76 Access: 20.10 .2021$.

30. Sinchenko, V., Fuchylo, Ya., Humentyk, M. (2015). Koryhuvannia dlia verby (Adjustments for willow). The Ukrainian Farmer (in Ukrainian).

31. Usenko, M.V. (2010). Kompleks malogabarytnyh mashyn dlya vyroshchuvannya odnorichnyh kultur na peresichnyi miscevosti (The small-size machine complex for growing non-perennial crops in rough terrain). Monograph. RVV LNU, Lutsk, p. 240 (in Russian).

32. Willowpedia. Retrieved: https://www.youtube.com/user/Willowpedia. Access: 20.10.2021.

33. Wimatec Mattes GMBH. Retrieved: http://www.wimatec-mattes.de. Access: 20.10.2021.

34. Wrobel, M., Mudryk, K., Jewiarz, M., Knapczyk, A. (2018). Impact of raw material properties and agglomeration pressure on selected parmeters of granulates obtained from willow and black locust biomass. Engineering for Rural Development. Jelgava, 23-25 May 2018, pp. 1933-1938.

35. Yermakov, S. (2017) Kierunki optymizacji maszyn dla sadzenia wierzby energetycznej. Skróty referetów i posterów Konferencji Naukowej pt. Inżyneria produkcji rolniczej i leśnej. Warszawa, 8-9 czzerwca 2017, p. 75-77.

36. Yermakov, S.V. (2017). Prospects for improvement of constructions for planting energy crops cuttings. Podilskyi visnyk: silske gospodarstvo, tekhnika, ekonomika, v. 2, pp. 37-45.

37. Yermakov, S., Hutsol, T., Ovcharuk, O., Kolosiuk, I. (2019). Mathematic simulation of cutting unloading from the bunker. Independent journal of management \& production v.10, n.7, Special Edition PDATU, 758-777. https://doi.org/10.14807/IJMP.V1017.909.

38. Yermakov, S., Hutsol, T., Mudryk, K., Dziedzic, K., Mykhailova, L. (2019). The analysis of stochastic processes in unloading the energy willow cuttings from the hopper. Environment, Technology, Resources. Rezekne; Latvia; $249-252$. https://doi.org/10.17770/etr2019vol3.4159.

39. Yermakov, S.V., Hutsol, T.D. (2018). Features of the heterogeneous rood-like materials outflow (by example of energy willow cutting). Technological and methodological aspects of agri-food engineering in young scientist research, p. 55-68.

40. Yermakov, S., Hutsol, T., Slobodian, S., Komarnitskyi, S., Tysh, M. (2018). Possibility of using automation tools for planting of the energy willow cuttings. Renewable Energy Sources: Engineering, Technology, Innovation. pp. 419-429. https://doi.org/10.1007/978-3-030-13888-2_42

41. Yermakov, S, Tulej, M., Tulej, W., Shevchuk, I. (2018). Analiz konstruktsiy avtomativ sadinnia (Construction analysis means of plantingi automation). Tendentsii ta perspektyvy rozvytku nauky i osvity $v$ umovakh hlobalizatsii. Vypusk 34 , Pereiaslav-Khmelnytskyi, pp.615-619 (in Ukrainian).

42. Yermakov, S. (2019). Application of the laplace transform to calculate the velocity of a two-phase fluid modulated by the movement of cuttings of an energy willow (Salix Viminalis). Teka. Quarterly journal of agri-food industry, v. 2, p. 71-78.

43. Yermakov, S., Boris, N. (2016). Sopostavlenie reshenij lesoposadochnyh mashin s trebovaniyami dlya energeticheskih drevesnyh kul'tur (iva, topol') (Comparison of planting machine solutions with requirements for energy tree crops (willow, poplar)). Sovremennyj nauchnyj vestnik. № 20-1 (267). Belgorod: Rusnauchkniga. pp. 67-68 (in Russian).

44. Yermakov, S.V., Borys, M.M. (2015). Analiz efektyvnosti ahrehativ dlia sadinnia enerhetychnoi verby (Efficiency analysis of the energy willow planting devices). Veda a vznik - 2015. Dil 14 Ekologie Zemepis a geologie Vystavba a architektura Zemedelstvi,Praha, pp. 47-49 (in Ukrainian).

45. Yermakov, S., Hutsol, T. Mudryk, K. (2018). Vykorystannia verby v enerhetychnykh i hospodarskykh tsiliakh (Using willow for energy and economic purposes). Tendentsii ta perspektyvy rozvytku nauky i osvity $\mathrm{v}$ umovakh hlobalizatsii, Pereiaslav-Khmelnytskyi, s.732-735 (in Ukrainian).

46. Yermakov, S., Hutsol, T., Mudryk, K. (2019). Peredumovy vyroshchuvannia enerhetychnoi verby v Ukraini (Prerequisites for growing energy willow in Ukraine). Enerhoefektyvnist: nauka, tekhnolohii, zastosuvannia. Kyiv, s.16-18 (in Ukrainian).

47. Yermakov S.V., Hutsol T.D. (2021). Investigation of the process of gravitational unloading of energy willow cuttings in the conditions of static and dynamic arches. Engineering of nature management, vip.3, s. 97-109.

48. Zyma, I.M., Maliutin, T.T. (2006). Mekhanizatsiia lisohospodarskykh robit (Mechanization of forestry works). Kyiv: INKOS, 488 p. (in Ukrainian). 
Yermakov S. V., Head of the DAK GPS Training and Research Laboratory, State Agrarian and Engineering University in Podilia, Kamianets-Podilskyi, Khmelnytsk region, Ukraine

Hutsol T. D., Doctor of Technical Sciences, Associate Professor, Polissia National University, Kamianets-Podilskyi, Khmelnytsk region, Ukraine

Potapskyj P. V., Candidate of Technical Sciences, Associate Professor, State Agrarian and Engineering University in Podilia, Kamianets-Podilskyi, Khmelnytsk region, Ukraine

Garasymchuk I. D., State Agrarian and Engineering University in Podilia, Kamianets-Podilskyi, Khmelnytsk region, Ukraine

Structuring the process of automation of planting plants of energy willow

Biomass energy is one of the most promising branches of renewable energy, primarily due to the possibility of rapidly increasing the production of raw materials. The creation of new plantations of energy crops requires appropriate technical means. And for energy willow or poplar, you should also take into account the features of planting material, which are woody cuttings $20-25 \mathrm{~cm}$ long and 6-16 mm in diameter. Known machines for planting cuttings of energy crops are characterized by low productivity due to the limitation of the speed of manual laying of cuttings in the planter. Therefore, the creation of mechanisms for automated planting of cuttings in planting machines is an urgent scientific and industrial task.

The study is based on the analysis of known designs of planting machines used in planting seedlings and seedlings for the forest. The analysis used the methods of structural-factor analysis of the structure of mechanisms, and highlighted the features of the work processes that occur at each stage of the overall technological process of moving cuttings from the technological tank to the planting site.

After analyzing the known technical solutions for planting forests, seedlings, potted materials and directly cuttings of energy crops, it was noted that the most problematic is the position responsible for feeding cuttings from containers with seedlings to the place of planting. In modern machines for planting energy willow, this process is performed exclusively by hand. Informationlogical searches led to the synthesis of the structural-logical scheme of the technological process of automated planting. According to this scheme, it is seen that the main operations that must be implemented in the planting machine are the narrowing of the flow of cuttings, piece selection, orientation and transportation of planting material to the planting site. Promising ways to automate the planting of cuttings of energy crops and possible problems on the way to their implementation are identified.

Key words: automatic planting machine, planter, feeding mechanism, cassette mechanism, planting machine, energy willow.

Дата надходження 27.08.2021 p. 